\title{
Notary's Responsibility after the Transfer of the Place of Work to The Completeness of the Notary Protocol in West Sumatra
}

\author{
Pegisya Arvio*; Azmi Fendri; Frenadin Adegustara \\ Faculty of Law, Universitas Andalas Padang, Indonesia \\ Email: pegisya.arvio@gmail.com
}

http://dx.doi.org/10.18415/ijmmu.v6i1.570

\begin{abstract}
The authority of the notary is very susceptible of legal violations. The role of the supervisory board is very important to maintain the notary profession in carrying out the authority. Law enforcement is urgently needed when a violation arises, in which a troubled notary must be sanctioned. The objectives of this study are: 1) to find out the transfer process of notary's place of work, 2) to find out the notary's responsibility after the transfer of his/ her place of work toward the completeness of the notary protocol, 3 ) to find out the legal consequences if a notary, who does the transfer of his/ her place of work, does not complete the notary protocol in the area of West Sumatra. This study applies juridical empirical approach using secondary and primary data types. The Regional Supervisory Board of Padang City mentioned that the causes of legal violations committed by a notary in Padang City are that (1) the notary likes to accept a work that is not in accordance with the date stated in the deed and (2) the notary often does not see the client directly. Prevention for legal violations committed by the notaries in Padang City can be carried out by conducting socialization and direct observation to the field. If a legal violation committed by a notary occurs, the action that needs to be taken is to carry out the inspection process to prove whether or not the notary has committed a violation.
\end{abstract}

Keywords: Notary; Notary Protocol; Legal Violation

\section{Introduction}

Indonesia is a legal state that is affirmed in the 1945 Constitution of the Republic of Indonesia Article 1 paragraph (3). The principle of the rule of law is the guarantee of legal certainty, legal order and legal protection that the law must be definite and fair so that it can function properly.Today, along with the development of the economy, people want regulations that guarantee the certainty between their relationships with each other. Moreover, in legal traffic, evidence to determine one's rights and obligations as a subject in social life is required. The main evidence in civil law is written evidence, while the strongest written evidence is in the form of an authentic deed (Santoso, 2015).

General official who can make authentic certificates is notary. The arrangement of notaries in Indonesia initially refers to the provisions of the Reglement op Het Notaris Ambt in Indonesie (Staatsblad 
1860 Number 3) or the Regulation of Notary Position (PJN) which are the inheritance rules of the Dutch East Indies and other statutory regulations which constitute legislation national in the notary field. Various provisions in the legislation are no longer in line with the development and legal needs of the Indonesian people. Therefore, it is necessary to conduct a renewal and reorganization as a whole in one law governing the notary position to create a legal unification that applies to all residents in the entire territory of the Republic of Indonesia. The government, together with the House of Representatives stipulates Law No. 30 of 2004 concerning the Notary Position which has been changed to Law No. 2 of 2014 (hereinafter referred to as UUJN), as part of positive law in Indonesia.

A notary is a public official, which means that the authority of a notary is never given to other officials; as long as the authority is not under the authority of other officials. In accordance with these provisions, the notary is the only official authorized to make authentic deeds regarding all acts, agreements, and stipulations required by a general regulation or by an interest desired to be stated in an authentic deed; as long as the making of the deed is based on a general rule that is not also assigned or excluded to officials or other people.The notary has an obligation to include what is contained in the notary deed in accordance with the wishes of the related parties, i.e. by reading it so that the contents of the notary deed become clear. Then, the parties sign the deed to declare that the deed is true. In addition, the notary also provides access to information, including access to legislation for related parties. Authentic deed, as the strongest and most fulfilled evidence, has an important role in every legal relationship in people's lives. In various business relationships, activities in the fields of banking, land, social activities, etc., the need for written proof in the form of authentic deeds is increasing in line with the demands for legal certainty that develops in various economic and social relations at the national, regional, and global level (San AP, 2018).

The notary is responsible for storing authentic deeds which are part of the notary protocol, namely in Article 1 number 13 UUJN. The documents included in the notary protocol are outlined in the explanation of Article 62 of the UUJN. The notary protocol must be submitted to other parties according to the provisions stipulated in Article 62 of the UUJN which determine the cause of submission of the notary protocol (Salim, 2016). One of the reasons for the submission of the notary protocol was the transfer of the place of work. Before the submission of the notary protocol, the notary who wants to move his/her place of work must first fulfill several conditions as stipulated in Article 23 UUJN. Notary protocol is part of the administration of a notary's office that has a very important function and role so that the notary can run a good and correct position. Therefore, the notary protocol as a state archive must be well organized and managed. The notary protocol is supervised by the Notary Supervisory Board; i.e. the Regional Supervisory Board. The Regional Supervisory Board has the authority as stipulated in Article 70 of the UUJN.

In addition, the authority of the Regional Supervisory Board is also regulated in the provisions of Article 23 of the Regulation of the Minister of Law and Human Rights of the Republic of Indonesia Number 40 of 2015 concerning Organizational Structure, Procedures for Appointment of Members, Dismissal of Members, and Procedures of the Supervisory Board. The notary is also directly responsible for maintaining the notary protocol that that he/she owns before being submitted to the notary recipient of the protocol. The notary protocol must be maintained and kept by a notary because it can be used as a valid and strong evidence. If at any time there are parties who have made a deed to the notary and the notary has no longer served as a notary or because of other things in which the notary protocol has moved to another notary, then the documents will be easily searched and found with the notary protocol that has been transferred to the notary who is assigned as the notary protocol holder. 


\section{Theoretical Framework 2.1 Responsibility Theory}

The legal responsibility theory is a theory that analyzes the responsibilities of legal subjects or actors who have committed acts against the law or criminal acts to bear costs or losses or carry out crimes for their mistakes or because of their negligence (Salim and Nurbani, 2014). In Indonesian, the word responsibility means that the condition must bear everything (if something happens, then someone may be sued, blamed, brought to justice, etc.). Bears are defined as being willing to bear the costs (managing, maintaining), guaranteeing, stating the state of willingness to carry out obligations. ${ }^{1}$ According to Hans Kelsen, in his theory of legal responsibility, states that "a person is legally responsible for a certain act or that he or she bears legal responsibility; the subject of the law means that he/ she is responsible for a sanction in the event of a contravention." Furthermore, Hans Kelsen stated that "failure to exercise caution which is required by law is called negligence. In addition, oversight is usually seen as one other type of error (culpa), although it is not as severe as the mistakes that are fulfilled because of anticipating and wanting, with or without evil intentions or harmful consequences."

Hans Kelsen divides responsibility as follows:

a. Individual responsibility means that an individual is responsible for his/her own violations.

b. Collective responsibility means that an individual is responsible for a violation committed by another person.

c. Responsibility based on error means that an individual is responsible for the violation he/she has committed because it is intentional and estimated with the aim of causing harm.

d. Absolute responsibility means that an individual is responsible for the violation he/she has committed because of accident and unexpected matters.

The responsibility, etymologically, is the obligation of everything or the function of accepting the burden as a result of the actions of themselves or other parties. Meanwhile, the understanding of responsibility, according to the Indonesian Dictionary is a condition that must bear everything. According to the Legal Dictionary, there are 2 (two) terms of liability, i.e. liability (the state of being liable) and responsibility (the state being responsible).Liability is a broad legal term which refers to a more comprehensive meaning and covers almost every character of risk or definite responsibility; dependent or possible. Liability is also a condition of submitting to actual or potential obligations, the condition is responsible for actual or possible matters such as loss, threat, crime, cost or expense, and conditions that create the task to implement the law immediately or in the future. In addition, responsibility means things can be accounted for or an obligation and includes decisions, skills, abilities and skills. Responsibility also means the obligation to be responsible for the laws implemented and to repair or otherwise compensate for any damage that has been caused. The principle of legal responsibility can be divided into 2 (two) types, i.e. liability based on fault and strict liability.

\subsection{Authority Theory}

The implementation of the functions of government, power and authority is very important. In the Big Indonesian Language Dictionary (KBBI), the word "authority" means the right and power to act,

\footnotetext{
${ }^{1}$ Departemen Pendidikan dan Kebudayaan (Department of Education and Culture), Kamus Besar Bahasa Indonesia (Indonesia Dictionary), Balai Pustaka, Jakarta, page 899.
} 
authority, power to make decisions, govern and delegate responsibility to others. ${ }^{2}$ According to Phillipus, in further examination, there is a slight difference between the term authority and the term bevoegheid. The difference lies in its legal character. The term bevoegheid is used in the concepts of public law and the concept of private law. In addition, in our law, the term authority should be used in the concept of public law. ${ }^{3}$ Authority is generally interpreted as the power to carry out all public legal actions. The authority of the notary is as a public official in charge of making authentic deeds, including the authority in attribution because notary authority is granted by direct law, namely Law Number 2 of 2014 Article 15 paragraph (1) which states that the notary is authorized to make authentic deeds.

\subsection{Legal Certainty Theory}

According to Kalsen, law is a norm system. Norms are statements that emphasize the "supposed" aspect or das sollen by including some rules about what to do. Norms are products and deliberative human actions (Marzuki, 2008). Legal certainty theory contains two meanings, as follows: ${ }^{4}$

a. General rules that make individuals know what is permissible and what is not.

b. Legal certainty for individuals from government arbitrariness.

By the existence of general legal rules, individuals can find out what the state can charge or do with individuals. Legal certainty is not only in the form of articles and laws but also consistency in judges' decisions between one judge's decision and the others for a similar case that has been decided. Basically, law is essentially an abstract matter, even though its manifestations are concrete. People's perception of the law is diverse; depending on which angle they look at. Judges will view the law from their point of view as judges, legal scientists will view the law from the point of their scientific profession, common people will view the law from their perspective and so on.Legal certainty is a question that can only be answered normatively, not sociologically. Normative legal certainty is when a regulation is defined and promulgated because it regulates clearly and logically. Obviously, in this case, it does not cause doubt (multi-interpretation) and logically is that it becomes a norm system with other norms so that it does not clash or does not cause norm conflicts.

\section{Research Method}

The approach that will be used in this study is an empirical juridical approach which in addition to seeing positive legal aspects, this study also looks at what is applied in the field and society (Cane and Herbert, 2010). The data examined initially are secondary data which are then followed by research on primary data in the field; i.e. research on the parties involved in carrying out the duties of notary position. This research is a descriptive analytical study that describes and explains the research object in a complete, clear and objective manner that has to do with research problems (Taylor et al., 2015). In this study, the authors describe the form of notary responsibility for the completeness of the notary protocol. This study uses the following data:

a. Primary data: data obtained directly in the field through interviews with respondents (notaries).

b. Secondary data that consists of legal materials such as:

1) Primary legal materials, i.e. binding legal materials such as legislation and jurisprudence, including:

a) 1945 Constitution of the Republic of Indonesia;

\footnotetext{
${ }^{2}$ Departemen Pendidikan dan Kebudayaan (Department of Education and Culture), Kamus Besar Bahasa Indonesia (Indonesia Dictionary), Balai Pustaka, Jakarta, page 1011.

${ }^{3}$ Phillipus M. Hadjon, Paper about Authority, Airlangga University, Surabaya, 1986, page 20.

${ }^{4}$ Ibid.
} 
b) Law Number 30 of 2004 concerning Notary Position;

c) Law Number 2 of 2014 concerning Amendment to Law Number 30 of 2004 concerning Notary Position;

2) Secondary legal material, namely legal material that provides an explanation of primary legal materials, among others:

a) Literature or the results of writing in the form of research findings including books, and scientific journals;

b) The work of legal practitioners and the writings of experts;

c) Legal theories and scholarly opinions through the literature they use.

3) Tertiary legal material, i.e. legal material that provides guidance and explanation of primary and secondary legal materials, such as legal dictionaries, and binding legal materials, especially in the area of notary.

Data collection required in this legal research is carried out using the following techniques:

a. Literature studies): research conducted by visiting the library in order to collect data relating to the research problem, which is carried out by studying documents. Document study includes the study of legal materials consisting of primary legal materials, secondary legal materials, and tertiary legal materials. Document study is a technique of collecting data by looking for the theoretical foundation of the problem under study by studying documents and data relating to the object to be studied.

b. Interview: the role of face-to-face person that is when the interviewer asks questions designed to obtain answers that are relevant to the research problem to the respondent. This interview is conducted by semi-structured technique, i.e. by making a list of questions in which during the implementation, the addition or development of questions with a focus on the problem under study is allowed.

\subsection{Data Processing and Analysis 4.1.1 Data Processing}

Before analyzing the data, the data found and collected is processed first by correcting the data obtained that include the findings in the field and the data that comes from books and legal rules. The way to process the data is through editing. Editing is the process of re-researching records, files, and information collected by data collector. ${ }^{5}$

\subsubsection{Data Analysis}

After processing the data that has been obtained, the authors then analyze the data qualitatively. Qualitative data analysis is an effort made by working with data; sort it into units that can be managed, search and find patterns, find what is important and what is learned (Moleong, 2013). Qualitative data analysis is not using numbers (not using mathematical formulas), but using sentences as the views of experts, legislation, including data that the authors obtain in the field that gives a detailed description of the problem to show the nature of descriptive research (Sukmadinata, 2007).

\section{Literature Review}

\subsection{Notary as General Officer}

Notary position is the position of a state official or public official. Based on the provisions in UUJN public officials are people who carry out some functions of the public and the state, especially in

\footnotetext{
${ }^{5}$ Amiruddin dan Zainal Asikin, Op. Cit., page 168.
} 
the field of civil law (Kusumawati, 2001). Notary definition is stipulated in Article 1 number 1 of UUJN which states that a notary is a public official. The term public official is a translation of openbare ambtenaren found in Article 1 of UUJN and Article 1868 Burgerlijk Wetboek. According to the legal dictionary, one of the meanings of ambtenaren is an official. Thus, openbare ambtenaren is an official who has duties related to the interests of the community. Openbare ambtenaren is defined as an official who is assigned the task of making an authentic deed that serves the interests of the community and such qualifications are given to the notary. The term or the word 'official' is interpreted as a government employee who holds a position, in other words "the official refers more to the person holding a position".

Position is a field of work or duty that is deliberately made by the rule of law for certain needs and functions and is continuous as a permanent work environment. Position is a legal subject that supports rights and obligations. A position can run well if the position is owned by many other legal subjects. The person appointed to carry out the position is called an official. A position will not be able to run without an official.From these descriptions, it can be concluded that the notary is a general official authorized to make authentic deeds and other authorities as determined in the applicable provisions. Notary is one of the public officials in Indonesia. General officials can make authentic deeds, but not all general officials can be considered as a notary; for instance, civil registry employees. A civil registry employee (ambtenaar van de burgerlijke stand), even though he/she is not a legal expert, he/she has the right to make authentic deeds for certain matters, for example to make birth certificates, marriage certificates and death certificates. ${ }^{6}$

Notary legal products are authentic deeds in the form of notary deeds and not all public officials have the authority to do so (Mayer, 2008). Notaries must have good knowledge and abilities in order to be able to express people's desires and needs into a deed. To be able to be appointed as a notary, someone fulfills the requirements as stipulated in Article 3 of the UUJN.The notary has the characteristics of being a position, a notary has certain authority, is appointed and dismissed by the government, does not receive a salary/ pension fund from the one who appoints him/her and accountability for his/her work to the society. The characteristics of a notary as a public office can be explained as follows:

1) Notary is a position

2) Notary has certain authority

3) Notary is appointed and dismissed by the Government

4) Notary does not receive salary/ pension fund from the one appoints him/her

5) Notary has accountability for their work to the society

If a notary carries out his office duties outside of the authority granted to him, the action can be referred to as an act of authority abuse. If the authority abuse causes the parties to suffer losses, the parties may hold the notary accountable. The notary must consider and see all the documents shown to him/her. This is in accordance with the principle of prohibiting arbitrary acts. ${ }^{7}$ The notary must prioritize the balance between the rights and obligations of the parties coming t the notary. ${ }^{8}$ This is based on Article 16 paragraph (1) letter a UUJN which states that the notary is required to act and safeguard the interests of the parties. Notaries must be able to consider the wishes of the parties so that their interests are maintained in a professional manner which is then set forth in the form of a notary deed. After that, the notary is obliged to provide services in accordance with the provisions of Article 16 paragraph (1) letter $\mathrm{d}$

\footnotetext{
${ }^{6}$ Habib Adjie, Indonesian Notary Law: Thematic Interpretation of Law No. 30 of 2004 concerning Notary Position, Op. Cit, page 128.

${ }^{7}$ Habib Adjie, Indonesian Notary Law: Thematic Interpretation of Law No. 30 of 2004 concerning Notary Position, Op. Cit, page 38.

${ }^{8}$ Ibid.
} 
UUJN unless there is a reason to reject it. This is in accordance with the principle of professionalism in which this principle prioritizes notary expertise.

\subsection{Implementation of the Supervision of Notary Obligations}

The Supervisory Board is an institution that has the authority and obligation to carry out guidance and supervision of the notary. This institution is formed by the Minister to delegate its obligations in supervising and guiding notaries, which includes behavior and implementation of the notary position. In Article 68 of the UUJN, supervision of Notaries is carried out by the Minister of Law and Human Rights by establishing a Supervisory Board. The Supervisory Board is functionally divided into several parts, according to the hierarchy and the division of an administrative region (Regency/ City, Province, and Central Area).

The notary position law has given birth to a new independent institution; i.e. the Honorary Board of Notaries (MKN). In the current UUJN, there is a new institution, called the Honorary Board of Notaries. However, unfortunately, Article 1 of the UUJN does not mention what is meant by the Honorary Board as explain the other institutions.By the stipulation of the regulation of the Minister of Law and Human Rights of the Republic of Indonesia Number 7 of 2016 concerning the Honorary Board of Notaries, to implement the provisions of Article 66A paragraph (3) of UUJN, the Honorary Board of Notaries was formed as a Supervisory Board. MKN is a body that has the authority to carry out notary guidance and provide approval or rejection of the interests of investigations and judicial processes for taking the copy of notarial deed and calling for notaries to be present at the examination relating to notary deeds or protocols in the notary's storage.

\subsection{Notary Protocol}

The Notary Protocol is regulated in Law Number 30 of 2004 concerning Notary Position and Law Number 2 of 2014 concerning Amendments to Law Number 30 of 2004 concerning Notary Position, as well as other laws and regulations. ${ }^{9}$ The provisions or articles governing the notary protocol are Law Number 2 of 2014 concerning Amendments to Law Number 30 of 2004 concerning Notary Position. In addition, notary protocol is also regulated in Law Number 43 of 2009 concerning Archives. Explanation of Article 62 of the UUJN states that those included in the notary protocol are as follows:

a. Notarial deed;

b. Book listing deed or repertories;

c. Book listing deeds under the acknowledgement of the signatory made before a Notary or deed under the acknowledgement of registered parties;

d. Book listing names of the viewers or the preceptors;

e. Book listing protests;

f. Book listing wills;

g. Another list book that must be kept by a notary based on the provisions of the law.

\footnotetext{
${ }^{9}$ Ibid, page 198.
} 


\subsection{Submission of the Notary Protocol}

Notary, substitute notary, and interim notary official are responsible for any deed that they made even though the notary protocol has been submitted or has been transferred to the notary protocol keeper in accordance with Article 65 UUJN. There are several conditions for a notary to submit the protocol; as stated in article 62 of the UUJN concerning the submission of the notary protocol.The Notary Protocol is submitted no later than 30 (thirty) days with proof in the form of a notary protocol submission report signed by the related party and those who receives the notary protocol (Article 63 UUJN). Meanwhile, Article 63 up to Article 65 of the UUJN has determined the parties that submit and those who receive the notary protocol. ${ }^{10}$

Submission of notary protocol from a notary to other notaries, as presented above, is alternative. The alternative means that the submission depends on the conditions of the notary concerned when exercising his/her authority. For instance, the notary concerned serves as Regent/Mayor, then he/she must submit the notary protocol to other notaries. The position as regent/mayor is a state official. ${ }^{11}$ The notary protocol that has been submitted to the notary recipient of the protocol also has a disadvantage for the notary him/herself. The advantage for notary recipients of the protocol is the increase in clients, partners from clients, and bank partners from previous notaries. The disadvantage is that if there is an error in the protocol (for instance, the notarial deed includes incomplete documents), the notary recipient of the protocol will experience difficulties if there are problems related to the protocol in the future. Then, in the case of notary protocol storage, the protocol notary recipient must provide additional storage or storage cabinets to store the notary protocol he/she will receive.

\section{Findings And Discussion}

Hans Kelsen's concept related to legal obligations is the concept of liability. A person is considered to be responsible for a particular act if he/she can be subject to a sanction in the case of an opposite act (Darus, 2017). The legal responsibility theory is needed to explain the relationship between notary responsibility relating to the authority of a notary based on UUJN which is in the context of civil law (Fitriyeni, 2012).A notary, in carrying out his/her position, has a moral responsibility towards his/her profession. Professional groups have their own power and special responsibilities. As a profession, this group has a reference called the Professional Code of Ethics (Farma, 2016). Violations of the notary's position will ultimately lead to accountability for the profession; administrative responsibility and civil compensation. Furthermore, a notary can be held criminally responsible if a notary public violates the Criminal Code in carrying out his/her duties and positions. ${ }^{12}$

For a notary who will retire, stop and or move his/her place of work, the notarial deeds and documents belong to the notary must be submitted to the holder of the notary protocol who has been appointed and approved by the Regional Supervisory Board (Sukisno, 2008). Since the notary protocol has been transferred to the notary who accepts the notary protocol, if there is a deed and documents required for the case review process, the notary recipient of the protocol may provide copies of the documents. The responsibility of a notary position must be carried out and held firmly in carrying out his/her position as a professional general officer, with trustworthiness, honesty, thoroughness, independence and impartiality. In addition, they must also maintain the honor and overall dignity, and be responsible as a notary to uphold truth and justice and strive for the realization of legal certainty in the context of devotion to God Almighty. Besides, the notary is also a trust institution that has authority from the state. Therefore, the notary has the right to use the state emblem during his/her term of office.

\footnotetext{
${ }^{10}$ Salim HS, Op. Cit, page 201.

${ }^{11}$ Ibid, page 202.

${ }^{12}$ M. Luthfan Hadi Darus, Op. Cit., page 49.
} 
In each deed making, a notary creates a new Law. In connection with the notary protocol, one of them is act which must be kept by the notary as a notary protocol. Act must be kept and maintained because if there is a problem between the parties on a deed, then they can look back on the agreement, in which the agreement has binding powers such as the Law.

Based on the results of interviews with Desrizal Notary, ${ }^{13}$ he stated that responsibility in this case does not mean the recipient of the notary protocol must be responsible for the contents of the deed made by another notary. If an error arises that requires the notary to be held accountable, whether civil or criminal liability, the claim is still directed at the notary who transfers the protocol, because the notary is responsible for the deed that he/she made for life. The recipient of the notary protocol is only administratively responsible for the notary protocol he/she receives. The recipient of the notary protocol is only responsible in terms of giving information and helping to provide a copy and showing the other notary deed that he/she has kept. However, he will not be prosecuted for the mistakes contained in the deed. However, if the recipient's notary eliminates the notarial deeds or documents he/she receives, then this notary can be prosecuted. The loss can be caused by deliberate or negligent notaries in the protocol storage.

Apart from those description above, there are several responsibilities of notary protocol holders, as follows: ${ }^{14}$

a. Provide information to related parties in using the deed that is part of the protocol he/she received. If there are parties needing information about the deed that is kept by the notary, the recipient of the notary protocol is responsible for explaining and giving information to the party. It is the same as giving a copy or excerpt and showing the notarial deed. Providing information about the contents of the deed may only be given to the concerned parties and their heirs before showing evidence that they are the authorized person to do so.

b. Make the second copy or Copy Collation.

c. Keep and maintain the notary protocol as state documents correctly in accordance with the Archival Law.

d. Refuse other unauthorized parties. If the client comes to the recipient of the notary protocol and asks for a copy or excerpt or asks to show the notarial deed while he/she is not a party to the deed and unable to prove that he/she is the party's heir, the recipient of the notary protocol must be brave and firmly reject the person.

e. Administer (registering) and store the protocol that he/she received properly. Protocol switching means the transfer of responsibility for storing the protocol. When a transfer occurs, the recipient of the notary protocol must properly store and make proper administration of the protocol and treat the protocol as its own protocol.

Apart from responsibility, there are several restrictions for the recipient of the notary protocol according to one notary, as follows: ${ }^{15}$

a. Change or edit the contents of the deed. The recipient of the notary protocol may not change or edit the contents of the deed that has been made by the previous notary, even if the deed contains a

\footnotetext{
${ }^{13}$ Interview with Notary Desrizal Idrul Hakimi, S.H., as Notary and PPAT of Padang City and the recipient of Notary Protocol, on Monday, April 10, 2018, at 11.00 West Indonesia Time.

${ }^{14}$ Interview with Notary Alexander SH., M.Kn., as Notary and PPAT of Padang City, on Thursday, May 4, 2018 at 14.00 West Indonesia Time.

${ }^{15}$ Interview with Notary Desrizal Idrul Hakimi, S.H., as Notary and PPAT of Padang City and the recipient of Notary Protocol, on Monday, April 10, 2018, at 11.00 West Indonesia Time.
} 
mistake. If he/she is required to make a copy or quote of the deed, the recipient of the notary protocol must make it exactly the same as the existing notarial deed; there must be no additions, deductions or omissions.

b. Show the contents of the deed to unauthorized parties. Before showing the contents of the deed to other parties, the notary must be careful and ask for evidence to the party who is willing to view the contents of the deed.

c. Eliminate the deed. The recipient of the notary protocol must keep and maintain the protocol he/she receives from other notaries, so that no deed is lost or tucked away. In the event of loss caused by negligence of the recipient of the notary protocol, he/she can be sued for his/her responsibility.

d. Divulge the contents of the deed. A notary is obliged to maintain the confidentiality of the contents of the deed. The obligation to keep this secret is not only to the deed itself but also to the deed received from other notaries transferred to him/her.

The responsibility of the Notary in UUJN is regulated in Article 16, Article 57, and Article 66, including:

a. Act honestly, independently, impartially and protect the interests of the parties involved in legal actions.

b. Make grosse deed, copy of the deed, or excerpt of the deed based on the notarial deed.

c. In this case, the deed refers to the original deed made by a notary who transfers the protocol.

d. Provide services in accordance with the provisions in this Law, unless someone refuses the reason.

In addition to the responsibilities regulated in UUJN, the holder of the notary protocol is also responsible for storing and maintaining the protocol he/she receives. Storing and maintaining appropriately is carried out by providing a good storage area, such as a proper and safe room and cupboard to store the contents of the deed. The appointed notary as the protocol holder signed a statement stating the willingness to receive the protocol as proof that he/she is willing to accept, store and manage the protocol. After signing the submission report, the recipient of the notary protocol is responsible for storing the protocol with all its consequences and should have stored the protocol in his/her notary's office.

The notary protocol that should be in the storage of the recipient of the notary protocol but still kept by the original owner of the notary protocol will cause new problems in the future. Regarding the making of a copy or excerpt of the deed, it will make it difficult for the recipient of the notary protocol to look for notarial deeds that are stored in other notary offices. It is not only related to making copies and excerpts only. Other problems that might arise are related to the responsibility of deed storage, which de jure has become the responsibility of the recipient of the notary protocol; while de facto is still kept by the original owner of the notary protocol. Regarding to this, matter if a deed cannot be found, no one will be responsible for losing the deed.The signing of the notary protocol submission report indicates that the responsibility of the initial notary to the holder of the notary protocol has been transferred in terms of the protocol storage. The responsibility here does not mean that the holder of the notary protocol must be responsible for the contents of the deed. Therefore, checking the completeness of the notary protocol should be carried out before the BAP is made from the handover of the notary protocol. This is also carried out to avoid misunderstandings in the future. If the protocol given to the recipient of the notary protocol is incomplete and is not checked before the BAP is made, then this will be a mistake by the 
holder of the notary protocol due to the incomplete protocol held by him/her. However, the contents of the deed made by the original notary remain his/her responsibility in accordance with Article 65 of the UUJN which states that the notary, substitute notary and temporary official notary are responsible for any deed they make even though the notary protocol has been submitted or transferred to other recipient of the notary protocol.

Based on the research conducted by the authors on September 13, 2018, in the office of the Ministry of Law and Human Rights in the Public Service Division, more precisely in the Regional Supervisory Board Office, there were three notaries who had transferred their place of work for the last 3 years. These notaries are: ${ }^{16}$

a. Notary Megya Lindra Mufti, S.H., M.Kn. whose protocol holder is Notary Indra Sakti, S.H., M.Kn., which took place in 2016.

b. Notary Desi Kurniati, S.H., M.Kn. whose protocol holder is Notary Sulastri, S.H., M.Kn., which took place in 2016.

c. Notary Hendra Idris, S.H., M.Kn. whose protocol holder is Notary Lusi Fatmasari, S.H., M.Kn., which took place in 2017.

The submission of the protocol carried out by the three notaries above has been legally handed over to the Regional Supervisory Board. Based on the results of interviews with Notary Indra Sakti S.H., M.Kn., ${ }^{17}$ Notary Sulastri S.H., M.Kn., ${ }^{18}$ and Notary Lusi Fatmasari S.H., M.Kn., ${ }^{19}$ each notary explained that the protocol they received was complete. However, from the three notaries, only Notary Sulastri mentioned that before carrying out the handover of the protocol, she firstly checked the compatibility of data and documents directly to Notary Desi Kurniati's office before the handover was carried out at the Regional Supervisory Office. Meanwhile, Notary Indra Sakti and Notary Lusi Fatmasari did not check the compatibility of data and documents against the protocol they received. According to Notary Indra Sakti and Notary Lusi Fatmasari, checking the compatibility of data and documents must have been carried out by the Regional Supervisory Board so that they only receive the protocol from the notary who submitted the protocol.Notary Sulastri ${ }^{20}$ also stated that the notary's obligation to maintain a notary protocol is to keep it in a closed cabinet to avoid insects, water, and so forth. It will minimize various possibilities that can cause damage or loss of the notary protocol that he/she keeps. In addition to this matter, the recipient of the notary protocol should record the protocol he/she received properly. This is intended to facilitate data collection at any time the authorized parties need the protocol and to facilitate the notary in checking the physical condition of the protocol.

Notary protocol is a collection of documents. As a state archive, it has a very important meaning for the notary in carrying out his/her position. Therefore, the obligation to prepare a notary protocol for a notary who will start running his/her position is an absolute step.In carrying out his position, the notary is obliged, one of which is to make a deed and keep it as part of the notary protocol as stipulated in Article 16 paragraph (1) letter b UUJN. The article explains that the obligation to keep notarial deeds, part of the notary protocol, is intended to maintain the authenticity of a deed by storing the deed in its original form. So, if there is forgery or misuse of grosse, copies, or excerpts, it can be immediately known by matching it to the original. However, the provisions of the UUJN do not explain how they are stored.

\footnotetext{
${ }^{16}$ Interview with Desmawita, SH, MH, as the member of MPD of Padang City, on Thursday, September 13, 2018 at 10.00 West Indonesia Time.

${ }^{17}$ Interview with Notary Indra Sakti S.H., M.Kn., as the recipient of Notary Protocol, on Friday, September 21, 2018, at 14.00 West Indonesia Time.

${ }^{18}$ Interview with Notary Sulastri S.H., M.Kn., as the recipient of Notary Protocol, on Friday, September 21, 2018, at 15.00 West Indonesia Time.

${ }^{19}$ Interview with Notary Lusi Fatmasari S.H., M.Kn., as the recipient of Notary Protocol, on Friday, September 21, 2018, at 11.45 West Indonesia Time.

${ }^{20}$ Interview with Notary Sulastri S.H., M.Kn., as the recipient of Notary Protocol, on Friday, September 21, 2018, at 15.00 West Indonesia Time.
} 
Since there are no statutory rules on how to store notarial deeds, in the storage of the state archives, notaries do not have standard procedures in carrying out these obligations. Thus, the notary protocol is vulnerable to damage, loss, and destruction.

Formally, the notary is responsible for the authenticity of the original deed he/she made. Furthermore, if there is a legal defect resulting in the deed losing its authenticity and harming the authorized parties, the notary may be required to reimburse costs, compensation, and interest. Regarding the material responsibility of the deed made before the notary, it needs to be emphasized that the notary's authority in making authentic deeds does not mean that the notary can make an original deed freely according to his/her wishes without the parties requesting a deed. Notarial deed is actually the deed of the authorized parties, not the deed of the relevant notary. Therefore, related to disputes in the agreement contained in the notary deed made for the parties concerned before the notary, the parties bound are those who entered into the agreement itself. Meanwhile, the notary is not bound to fulfill any promises or obligations as stated in the notary deed made before him. In other words, a notary is outside the scope of the parties concerned.

Legal protection against the maker of notary protocol must be carried out because there is an incident that the notary protocol is lost after the submission which is not solely carried out by the maker of the notary protocol. The maker might be responsible there is a problem with the contents of the deed which he/she made during his/her assignment not after he/she transferred his/her notary protocol. Then, it is lost or damaged in the hands of the recipient or the notary protocol.Notary Desrisal ${ }^{21}$ stated that if there was a civil case involving the protocol held by the recipient of the notary protocol, the recipient notary could provide information regarding the administration of the deed he/she held. However, if there is a criminal case involving the protocol that he/she is holding, then the responsible person is the owner of the notary protocol on the deed he/she has made. In this case, what is still a dilemma is who will call the notary. Based on existing rules, the police can call a notary through the Regional Supervisory Board. The West Sumatra Regional Supervisory Board can no longer call a notary who has moved from West Sumatra because he/she is no longer in his/her working area.

The notary who submits the protocol that includes incompleteness and the case concerning the protocol after the handover was carried out, he/she could no longer be called by the Regional Supervisory Board of West Sumatra because the notary was no longer in the scope of the Regional Supervisory Board of West Sumatra. The same thing applies to the Regional Supervisory Board where the notary moves because the case that occurs is not within the scope of his/her working area as well. That is still a debate until now and this is also caused by the absence of a law regulating this matter.

To answer the second problem, the author uses the responsibility theory. According to this theory, the notary has responsibility for the completeness of the protocol when moving to a place where legal responsibility theory is a theory that analyzes the responsibilities of legal subjects or actors who have committed unlawful acts or criminal acts to bear costs or losses or carry out crimes for their mistakes. or because of his/her negligence.

\section{Conclusions}

Based on the research findings that the author has described in the previous sections the following points can be concluded:

a. The process of transferring notary's place of work in West Sumatra must fulfill several conditions which have been regulated in Article 23 of UUJN. The procedure for the transfer of a notary in West Sumatra has been carried out according to legal procedures in the Minister of Law and

\footnotetext{
${ }^{21}$ Interview with Notary Desrizal Idrul Hakimi, S.H., as Notary and PPAT of Padang City and the recipient of Notary Protocol, on Monday, September 19, 2018, at 16.00 West Indonesia Time.
} 
Human Rights Regulation of the Republic of Indonesia Number: M.01.HT.03.01 of 2006 concerning Terms and Procedures for Appointment, Displacement and Dismissal of Notaries.

b. Notary's responsibility after the transfer of place of work to the completeness of the notary protocol is before the signing of the report of the notary protocol submission in which the notary must reexamine the notary protocol to be submitted to the recipient of the notary protocol.

c. The legal effect if a notary in West Sumatra moves his/her place of work without completing the notary protocol is that he/she will receive an administrative sanction in the form of an oral warning letter by the Regional Supervisory Board to the notary. The reality in the implementation was that there were no cases of protocol completeness so that the sanction did not exist.

\section{References}

Agus Santoso, H.M. (2015). Hukum. Moral dan keadilan. Jakarta: PT. Fajar Interpratama Mandiri.

Cane, P., \& Kritzer, H. (Eds.). (2010). The Oxford handbook of empirical legal research. OUP Oxford.

Darus, M. L. H. (2017). Hukum Notariat Dan Tanggungjawab Jabatan Notaris, Yogyakarta : UII Press.

Farma, F. (2016). Penerapan Asas Kehati-Hatian Dalam Pembuatan Akta Otentik Oleh Notaris (Doctoral dissertation, Fakultas Hukum UNISSULA).

Fitriyeni, C. E. (2012). Tanggung Jawab Notaris terhadap Penyimpanan Minuta Akta sebagai Bagian dari Protokol Notaris. KANUN: Jurnal Ilmu Hukum, 14(3), 391-404.

Keputusan Menteri Hukum dan Hak Asasi Manusia Republik Indonesia Nomor : M-01.HT.03.01 Tahun 2003 Tentang Kenotarisan.

Kitab Undang Undang Hukum Perdata

Kusumawati, L. (2001). Tanggung jawab Jabatan Notaris (Doctoral Dissertation, Universitas Airlangga). Lexy, J. M. (2013). Metodologi Penelitian Kualitatif. Bandung: Remaja Rosdakarya.

Marzuki, P. M. (2008). Pengantar Ilmu Hukum, Jakarta : Kencana.

Mayer, D. (2008). "Notary document processing and storage system and methods." U.S. Patent Application No. 11/586,118.

Peraturan Menteri Hukum dan Hak Asasi Manusia Nomor 27 Tahun 2016 Tentang Formasi Jabatan Notaris dan Penentuan Kategori Daerah.

Peraturan Menteri Hukum dan Hak Asasi Manusia Republik Indonesia Nomor M-01.HT.03.01 Tahun 2006 tentang Syarat dan Tata Cara Pengangkatan, Perpindahan, dan Pemberhentian Notaris.

Peraturan Menteri Hukum Dan Hak Asasi Manusia Republik Indonesia Nomor 40 Tahun 2015 tentang Susunan Organisasi, Tata Cara Pengangkatan Anggota, Pemberhentian Anggota dan Tata Kerja Majelis Pengawas. 
Peraturan Menteri Hukum dan Hak Asasi Manusia Republik Indonesia Nomor 62 Tahun 2016 Tentang Perubahan Atas Peraturan Menteri Hukum dan Hak Asasi Manusia Nomor 25 Tahun 2014 Tentang Syarat dan Tata Cara Pengangkatan, Perpindahan, Pemberhentian dan Perpanjangan Masa Jabatan Notaris, Tata Cara Perpindahan Notaris.

Peraturan Pemerintah Nomor 10 Tahun 2015 Tentang Perubahan Atas Peraturan Pemerintah Nomor 45 Tahun 2014 Tentang Jenis dan Tarif atas Jenis Penerimaan Negara Bukan Pajak yang Berlaku Pada Kementerian Hukum dan Hak Asasi Manusia.

Phillipus, M. H. (1986). Makalah Tentang Wewenang. Surabaya: universitas airlangga.

Salim, H. S. (2016). Teknik Pembuatan Akta Satu (Konsep Teoritis, Kewenangan Notaris, Bentuk dan Minuta Akta), Jakatra : PT. Raja Grafindo Persada.

Salim, H. S., \& Nurbani, E. S. (2014). Penerapan Teori Hukum Pada Penelitian Disertasi dan Tesis. PT Raja Grafindo Persada, Jakarta.

San AP, K. A. (2018). Review Of Legal Execution Testment And It's Problem (Studi in Sunarto, SH Notary Public Office Surakarta). Karya Ilmiah Mahasiswa Fak. Hukum, 3(2).

Sukisno, D. (2008). "Pengambilan Foto Copi Minuta Akta dan Pemanggilan Notaris." Mimbar HukumFakultas Hukum Universitas Gadjah Mada 20.1.

Sukmadinata, N. S. (2007). Metode penelitian. Bandung: PT Remaja Rosda Karya.

Taylor, S. J., Bogdan, R., \& DeVault, M. (2015). Introduction to qualitative research methods: A guidebook and resource. John Wiley \& Sons.

Undang Undang Dasar 1945.

Undang-Undang Nomor 2 Tahun 2012 Tentang Perubahan Atas Undang-Undang Nomor 30 Tahun 2007 Tentang Jabatan Notaris.

Undang-Undang Nomor 30 Tahun 2007 Tentang Jabatan Notaris.

\section{Copyrights}

Copyright for this article is retained by the author(s), with first publication rights granted to the journal.

This is an open-access article distributed under the terms and conditions of the Creative Commons Attribution license (http://creativecommons.org/licenses/by/4.0/). 